\title{
Crown Ethers Assisted Cesium Extraction from Aqueous Solutions into a Hydrophobic Room Temperature Ionic Liquid 1-Butyl-3-methylimidazolium Bis[(trifluoromethyl)sulfonyl]imide
}

\author{
Andrey G. Vendilo, Vyacheslav I. Chistov, Julia M. Dikareva, \\ and Konstantin I. Popov ${ }^{\circledR}$ \\ RJSC R\&D Fine Chemicals Centre, 107564 Moscow, Russia \\ ${ }^{@}$ Corresponding author E-mail:ki-popov49@yandex.ru
}

\begin{abstract}
Crown ethers (L) assisted extraction of $C s^{I}$ from aqueous neutral solutions (pH 5-6) into a hydrophobic ionic liquid 1-butyl-3-methylimidazolium bis[(trifluoromethyl)sulfonyl]imide was studied at $22{ }^{\circ} \mathrm{C}$ operating with: 12-crown-4 (12C4), 15-crown-5 (15C5), 18-crown-6 (18C6), dibenzo-18-crown-6 (DB18C6), dibenzo-21-crown-7 (DB21C7) and dibenzo-24-crown-8 (DB24C8). The distribution coefficients $\left(\log D_{C s}{ }^{L}\right)$ are found to increase from 0.30 do 1.7 as the size of L is changing from $15 C 5$ to DB21C7. A further increase of L size (DB24C8) leads to a sufficient decrease of logD ${ }_{C S}{ }^{2}$ up to 0.9. The maximal $\log D_{C s}{ }^{L}$ value corresponds to the better cation-crown ether fitting. Well expressed correlation between $\log D_{C s}{ }^{L}$ values and stability constants of $C s L$ in ionic liquid $\left(\log K_{C S L}\right)$ is obtained and is interpreted for the crown ether series.
\end{abstract}

Keywords: Cesium, extraction, crown ethers, room temperature ionic liquids.

\section{Экстракция ионов цезия в присутствии краун-эфиров из нейтральных водных растворов в гиАрофобную ионную жиАкость бис[(трифторметил)сульфонил]имиА 1-бутил-3-метилимидазолия}

\author{
А. Г. Вендило, В. И. Чистов, Ю. М. Аикарева, К. И. Попов ${ }^{\circledR}$ \\ ПАО Научный цеентр «Малотоннажная химия», 107564 Москва, Россия \\ ${ }^{\circledR}$ E-mail: ki-popov49@yandex.ru
}

\begin{abstract}
Изучена экстракция $C s^{I}$ из нейтральных водных растворов (pH 5-6) в гидрофобную ионную жидкость бис[(трифторметил)сульфонил]имид 1-бутил-3-метилимидазолия ([BMIM][N(Tf) $]$ ]) в присутствии серии краун-эфиров (L): 12-краун-4 (12C4), 15-краун-5 (15C5), 18-краун-6 (18C6), дибензо-18-краун-6 (DB18C6), дибензо-21-краун-7 (DB21C7) и дибензо-24-краун-8 (DB24C8) при $22{ }^{\circ} \mathrm{C}$. Показано, что коэффициенты распределения $\left(\log D_{C s}{ }^{L}\right)$ монотонно возрастают при переходе от $15 C 5 \kappa$ DB21C7 от 0.30 до 1.7, а затем снижаются до 0.9 (DB24C8). Максимальное значение $\log D_{C s}{ }^{2}$ наблюдается для краун-эфира с наилучшим соответствием размера полости ионному радиусу катиона. Для исследованных краун-эфиров выявлена и объяснена линейная корреляияя между $\log D_{C s}{ }^{L}$ и константами устойчивости комплексных соединений CsL $в$ ионной жидкости $\left(\log K_{C s L}\right)$.
\end{abstract}

Ключевые слова: Цезий, экстракция, краун-эфиры, ионная жидкость. 


\section{Introduction}

Hydrophobic crown ethers are widely used for a selective extraction of cations from aqueous solution into organic phase. ${ }^{[1-5]}$ Recently the hydrophobic room temperature liquids (RTILs) are intensively studied as an alternative to the volatile and flammable conventional organic solvents. ${ }^{[6-11]}$ An increasing interest is observed towards extraction of radionuclides, ${ }^{[9,11]}$ lanthanides, ${ }^{[12]}$ copper, ${ }^{[13]}$ lithium, ${ }^{[14]}$ and other metals. Intensive studies in this field were initiated since an outstanding dicyclohexyl-18-crown-6 assisted removal of strontium from aqueous solution into triflimide-based RTIL has been reported. The corresponding distribution coefficient $D_{\mathrm{Sr}}^{\mathrm{L}}=1.1 \cdot 10^{4[6]}$ was incomparably higher than that for toluene (0.76) and chloroform (0.77). ${ }^{[9]}$

Our previous studies of cesium extraction into six hydrophobic RTILs in presence of 18-crown-6 $(18 \mathrm{C} 6, \mathrm{~L})$ and dibenzo18-crown-6 (DB18C6, L) run in the wide $\mathrm{pH}$ range, reveal a rather complicated correlation between the stability constant of CsL complexes in RTIL $\left(\log K_{\mathrm{CsL}}\right)$ and cesium distribution coefficient $\left(\log D_{\mathrm{CS}}{ }^{\mathrm{L}}\right){ }^{[15,16]}$ In present paper an extraction of $\mathrm{Cs}^{\mathrm{I}}$ from neutral aqueous solutions into 1-butyl3-methylimidazolium bis[trifluoromethyl)sulphonyl]imide $\left([\mathrm{BMIM}]\left[\mathrm{N}(\mathrm{Tf})_{2}\right]\right)$ (Figure 1$)$ at $22{ }^{\circ} \mathrm{C}$ for a series of crown ethers with monotonously increasing cavity size, and known $\log K_{\mathrm{CsL}}$ value is considered: 12-crown-4 $(12 \mathrm{C} 4, \mathrm{~L})$, 15-crown-5 (15C5), 18C6, DB18C6, dibenzo-21-crown-7 (DB21C7, L) and dibenzo-24-crown-8 (DB24C8, L).

\section{Experimental}

1-Butyl-3-methylimidazolium bis[trifluoromethyl)sulphonyl] imide (Sigma-Aldrich) was used without additional treatment. Reagent grade crown ethers 12C4, 15C5, 18C6, DB18C6, DB21C7, and DB24C8 have been also supplied by Sigma-Aldrich, while $\mathrm{CsNO}_{3}$ sample was purchased from Merck.

Cesium distribution coefficients $D_{\mathrm{Cs}}{ }^{\mathrm{L}}$ have been measured after 2 hours shaking of $10 \mathrm{ml}$ of $0.001 \mathrm{MCsNO}_{3}$ neutral aqueous solution,

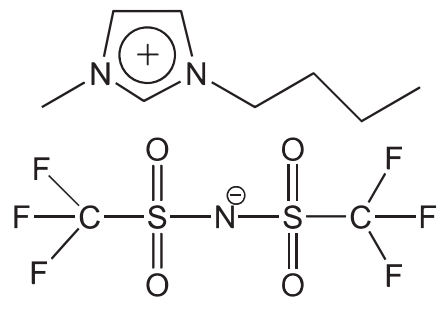

Figure 1. Chemical formula of $[\mathrm{BMIM}]\left[\mathrm{N}(\mathrm{Tf})_{2}\right]$. and $1 \mathrm{ml}$ of $0.1 \mathrm{M}$ crown ether solution in RTIL at $22{ }^{\circ} \mathrm{C}$. After organic and aqueous phases separation the residual concentration of cesium in an aqueous phase was measured operating ICP iCAP 6000 instrument (model iCAP 6300 Duo).

An extraction degree $\left(R_{C s}{ }^{L}, \%\right)$ and the distribution coefficient $\left(D_{\mathrm{Cs}}{ }^{\mathrm{L}}\right)$ have been calculated according to equations (1) and (2):

$$
\begin{aligned}
& \mathrm{R}_{\mathrm{Cs}}^{\mathrm{L}}, \%=\left(1-\frac{\mathrm{C}_{\mathrm{w}}(\mathrm{Cs})}{\mathrm{C}_{0}(\mathrm{Cs})}\right) \times 100 \%, \\
& \mathrm{D}_{\mathrm{Cs}}^{\mathrm{L}}=\frac{\mathrm{C}_{\mathrm{o}}(\mathrm{Cs})}{\mathrm{C}_{\mathrm{w}}(\mathrm{Cs})}=\frac{\mathrm{V}_{\mathrm{w}}}{\mathrm{V}_{\mathrm{o}}} \cdot \frac{\mathrm{R}_{\mathrm{Cs}}^{\mathrm{L}} \%}{100-\mathrm{R}_{\mathrm{Cs}}^{\mathrm{L}} \%},
\end{aligned}
$$

where $C_{0}(C s)$ and $C_{w}(C s)$ indicate the initial and equilibrium cesium concentrations in aqueous phase, while $V_{w}$ and $V_{o}$ correspond to the total volumes $(\mathrm{ml})$ of aqueous and organic phases respectively. The standard errors of $R_{C S}{ }^{L}$, and $\mathrm{D}_{\mathrm{Cs}}{ }^{\mathrm{L}}$ measurement are estimated to be within $10 \%$.

The results are presented in Table 1 and Figures 2, 3. Where it is possible the extraction data are referred to the stability constants of cesium with crown ethers in aqueous $\left(\log K_{\mathrm{ML}}{ }^{\mathrm{w}}\right)$ and in RTIL phase $\left(\log K_{\mathrm{ML}}{ }^{\mathrm{RTL}}\right) \cdot{ }^{[17-20]}$ The priority was given to the IUPAC critically evaluated values. ${ }^{[17]}$

\section{Results and Discussion}

When $\mathrm{L}$ is not present in $[\mathrm{BMIM}]\left[\mathrm{N}(\mathrm{Tf})_{2}\right]$, then cesium is poorly extracted. The corresponding $\log D_{\mathrm{Cs}}$ value constitutes $-0.67 .^{[16]}$ An administration of $\mathrm{L}$ into a RTIL phase enhances cesium accumulation (Table 1). For $18 \mathrm{C} 6$ and DB18C6 the $\log D_{\mathrm{Cs}}^{\mathrm{L}}$ values agree well with those found by us earlier::[16] 1.56 and 2.06 respectively. The higher values reported in ${ }^{[16]}$ in comparison with present data are due to the higher $\mathrm{L} / \mathrm{Cs}$ mole ratio $\left(C(18 \mathrm{C} 6)_{0}=1.5 \cdot 10^{-1} \mathrm{~mol} \cdot \mathrm{dm}^{-3}, C\left(\mathrm{Cs}^{+}\right)_{0}=5 \cdot 10^{-4} \mathrm{~mol} \cdot \mathrm{dm}^{-3}\right)$ relative to the present study. An increase of L/Cs leads to a higher $\log D_{\mathrm{Cs}}^{\mathrm{L}}$ values. It should be noted that relative to 1,2-dichloroethane $(1,2 \mathrm{DCE})$ in presence of $18 \mathrm{C} 6\left(\log D_{\mathrm{Cs}}\right.$ $0.8)^{[5]}$ the RTIL medium appears to be much preferable $\left(\log D_{\mathrm{Cs}} 1.3\right)$. The similar effect was also observed for dicyclohexane-18-crown-6 assisted cesium extraction into [BMIM] $\left[\mathrm{N}(\mathrm{Tf})_{2}\right]$ and 1,2DCE: $D_{\mathrm{Cs}}{ }^{\mathrm{L}}$ for RTIL constituted 80, while for $1,2 \mathrm{DCE} 0.080 .{ }^{[9]}$ Actually the differences between $[\mathrm{BMIM}]\left[\mathrm{N}(\mathrm{Tf})_{2}\right]$ and $1,2 \mathrm{DCE}$ are even more drastic as far as L concentration was smaller for RTIL $\left(0.01 \mathrm{~mol} \cdot \mathrm{dm}^{-3}\right)$ than for $1,2 \mathrm{DCE}\left(0.43 \mathrm{~mol} \cdot \mathrm{dm}^{-3}\right) \cdot{ }^{[9]}$

In our case within the set of crowns $12 \mathrm{C} 4,15 \mathrm{C} 5,18 \mathrm{C} 6$, DB18C6, DB21C7 and DB24C8 the $D_{\mathrm{Cs}}{ }^{\mathrm{L}}$ are changing in a non monotonous way as the cavity size ${ }^{[22,23]}$ is increasing, indicating a maximal value for DB21C7 (Table 1, Figure 2).

Table 1. The $D_{\mathrm{Cs}}^{\mathrm{L}}$ values for a crown ether assisted cesium extraction from aqueous solution into [BMIM] $\left[\mathrm{N}\left(\mathrm{Tf}_{2}\right)\right]$ at $22^{\circ} \mathrm{C}$.

\begin{tabular}{ccccccc}
\hline $\mathrm{L}$ & $R_{\mathrm{CS}}{ }^{\mathrm{L}}, \%$ & $D_{\mathrm{Cs}}{ }^{\mathrm{L}}$ & $\log D_{\mathrm{Cs}}{ }^{\mathrm{L}}$ & $\log K_{\mathrm{CSL}}{ }^{\mathrm{RTIL}}$ & $\log K_{\mathrm{CsL}}{ }^{\mathrm{w}}$ & Crown cavity size $R_{\mathrm{L}}, \mathrm{nm}^{[22,23]}$ \\
\hline $12 \mathrm{C} 4$ & \multicolumn{2}{c}{ Extraction is not detected } & $1.42^{[19]}$ & No data & 0.06 \\
$15 \mathrm{C} 5$ & 17 & 2.0 & 0.30 & $1.75^{[19]}$ & $0.80^{[17]}$ & $0.086-0.092$ \\
$18 \mathrm{C} 6$ & 50 & 19 & 1.3 & $3.40^{[19]}$ & $0.96^{[17]}$ & $0.134-0.143$ \\
DB18C6 & 26 & 14 & 1.3 & $3.47^{[20]}$ & $0.74^{[21]}$ & $0.134-0.143$ \\
DB21C7 & 82 & 47 & 1.7 & $3.52^{[20]}$ & No data & 0.17 \\
DB24C8 & 46 & 8.6 & 0.9 & $2.91^{[20]}$ & $1.41^{[21]}$ & 0.20 \\
\hline
\end{tabular}




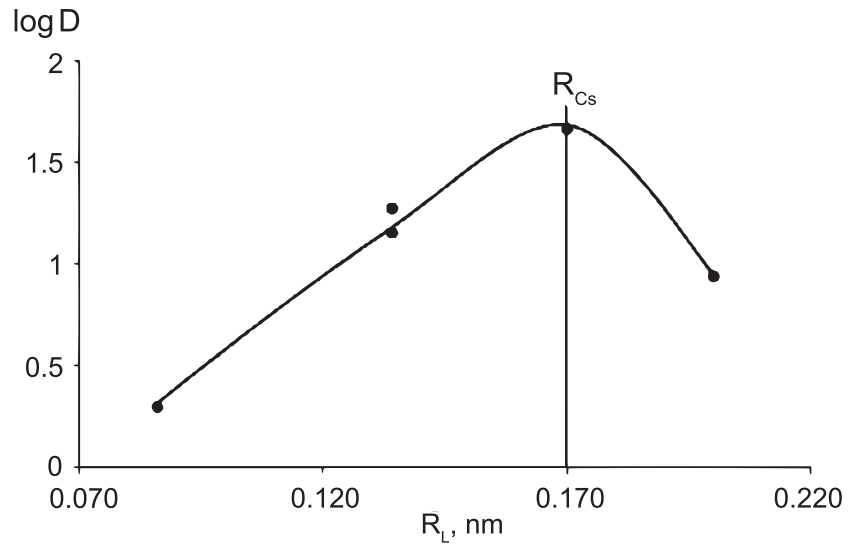

Figure 2. $\log D_{\mathrm{Cs}}{ }^{\mathrm{L}}(\log D)$ dependence on the crown cavity size $\mathrm{R}_{\mathrm{L}}$ for 15C5, 18C6, DB18C6, DB21C7 and DB24C8.

Indeed, for $12 \mathrm{C} 4,15 \mathrm{C} 5,18 \mathrm{C} 6$ and $\mathrm{DB} 18 \mathrm{C} 6$ the cavity size is smaller than cesium ion diameter $\left(0.17 \mathrm{~nm}^{[22]}\right)$, while for DB24C8 it is remarkably bigger. According to the crystallographic data and the structural data for the aqueous phase ${ }^{[24,25]}$ the cesium cation in its complexes with 18C6 is placed slightly above the plane, constituted by the oxygen atoms of the ligand, being a bit bigger than the cave size. The best cation-cave fitting should take place for DB21C7. Then a change of DB21C7 for DB24C8 should lead to some decrease of CsL thermodynamic stability $\left(\log K_{\mathrm{CsL}}{ }^{\mathrm{RTIL}}\right)$, and therefore, to a corresponding decrease in the extraction efficiency.

As could be seen from the Table 1 , the $\log K_{\mathrm{CsL}}{ }^{\mathrm{RTIL}}$ values are sufficiently higher than those for the aqueous phase $\left(\log K_{\mathrm{CsL}}{ }^{\mathrm{w}}\right)$. At the same time both $\log \mathrm{K}_{\mathrm{CsL}}{ }^{\mathrm{RTIL}}$ and $\log \mathrm{D}_{\mathrm{Cs}}{ }^{\mathrm{L}}$ values change in a similar way as the crown cavity size is increasing. In turn it gives a linear correlation between $\log D_{\mathrm{CS}}^{\mathrm{L}}$ and $\log K_{\mathrm{CSL}}{ }^{\mathrm{RTIL}}$ (Figure 3 ) with the slope $\sim 1.4$ and $R^{2}=0.88$.

A linear correlation between $\left(\log D_{\mathrm{Cs}}^{\mathrm{L}}-\log D_{\mathrm{Cs}}-\log D_{\mathrm{L}}\right)$ and $\log K_{\mathrm{CsL}}{ }^{\mathrm{RTIL}}$ has been observed by us earlier for $[\mathrm{Cs}(18 \mathrm{C} 6)]^{+}$and $[\mathrm{Cs}(\mathrm{DB} 18 \mathrm{C} 6)]^{+}$complexes in six hydrophobic RTILs, ${ }^{[15,20]}$ where $\log D_{\mathrm{Cs}}$ corresponds to a cesium distribution without crown ether, while $\log D_{\mathrm{L}}$ - to the distribution of $\mathrm{L}$ between aqueous and RTIL phases. Meanwhile, a direct correlation between $\log D_{\mathrm{Cs}}{ }^{\mathrm{L}}$ and $\log K_{\mathrm{CsL}}{ }^{\mathrm{RTIL}}$ was not detected for these systems.
Such a correlation indicates a dominating role of complex formation in a RTIL phase in the crown ether assisted extraction processes. For cesium transfer from neutral aqueous solution into RTIL phase an ion exchange

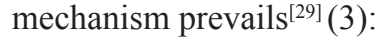

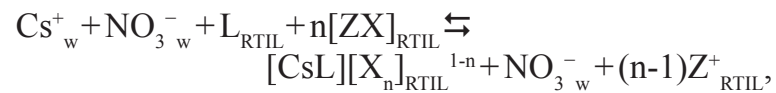

where indexes "RTIL" and "w" denote organic and aqueous phase respectively, while $\mathrm{Z}^{+}$and $\mathrm{X}^{-}$correspond to the RTIL's cation and anion, and $\mathrm{L}$ indicates a crown ether molecule.

Neglecting a small contribution of $\left[\mathrm{Cs}(18 \mathrm{C} 6)_{2}\right]^{+}$and $\left[\mathrm{Cs}(\mathrm{DB} 18 \mathrm{C} 6)_{2}\right]^{+}$species in $[\mathrm{BMIM}]\left[\mathrm{N}(\mathrm{Tf})_{2}\right]$ to the total thermodynamic stability, one can express the distribution coefficient of cesium between aqueous and [BMIM] $\left[\mathrm{N}(\mathrm{Tf})_{2}\right]$ phases in presence of crown ethers $D_{\mathrm{Cs}}{ }^{\mathrm{L}}$ by a rather simple equation (4):

$D_{\mathrm{Cs}}^{\mathrm{L}}=\left([\mathrm{Cs}]^{\mathrm{RTIL}}+[\mathrm{CsL}]^{\mathrm{RTIL}}\right) /\left([\mathrm{Cs}]^{\mathrm{w}}+[\mathrm{CsL}]^{\mathrm{w}}\right)$

As far as the total concentration of $\mathrm{L}[\mathrm{L}]^{\circ}>[\mathrm{Cs}]^{\circ}$ (total cesium concentration); the stability constants of CsL complexes in a RTIL phase are high enough $\left(\log K_{\mathrm{CIL}}{ }^{\mathrm{RTIL}} \geq\right.$ 2 ), and $[\mathrm{L}]^{\mathrm{RTIL}}>>[\mathrm{Cs}]^{\mathrm{RTIL}}$, then $[\mathrm{Cs}]^{\mathrm{RTIL}}<<[\mathrm{CsL}]^{\mathrm{RTIL}}$ and equilibrium concentrations $[\mathrm{Cs}]^{\mathrm{RTIL}}$ could be neglected. At the same time for an aqueous phase the $\log K_{\mathrm{CsL}}{ }^{\mathrm{w}}$ are comparatively small, and $[\mathrm{CsL}]^{\mathrm{w}}<<[\mathrm{Cs}]^{\mathrm{w}}$. Thus, $[\mathrm{CsL}]^{\mathrm{w}}$ values can be neglected. Therefore (4) can be transmitted into (5):

$$
D_{\mathrm{Cs}}^{\mathrm{L}}=[\mathrm{CsL}]^{\mathrm{RTIL}} /[\mathrm{Cs}]^{\mathrm{w}}
$$

or

$D_{\mathrm{Cs}}^{\mathrm{L}}=\left(K_{\mathrm{CsL}}{ }^{\mathrm{RTIL}}[\mathrm{Cs}]^{\mathrm{RTIL}}[\mathrm{L}]^{\mathrm{RTIL}}\right) /[\mathrm{Cs}]^{\mathrm{w}}$.

Taking into account that $[\mathrm{Cs}]^{\mathrm{RTIL}} /[\mathrm{Cs}]^{\mathrm{w}}=D_{\mathrm{Cs}}$ the following expression is valid:

$D_{\mathrm{Cs}}^{\mathrm{L}}=K_{\mathrm{CsL}}^{\mathrm{RTIL}} D_{\mathrm{Cs}}[\mathrm{L}]^{\mathrm{RTIL}}$

or

$\log D_{\mathrm{Cs}}{ }^{\mathrm{L}}=\log K_{\mathrm{CSL}}{ }^{\mathrm{RTIL}}+\log D_{\mathrm{Cs}}+\log \left([\mathrm{L}]^{\mathrm{RTIL}}\right)$

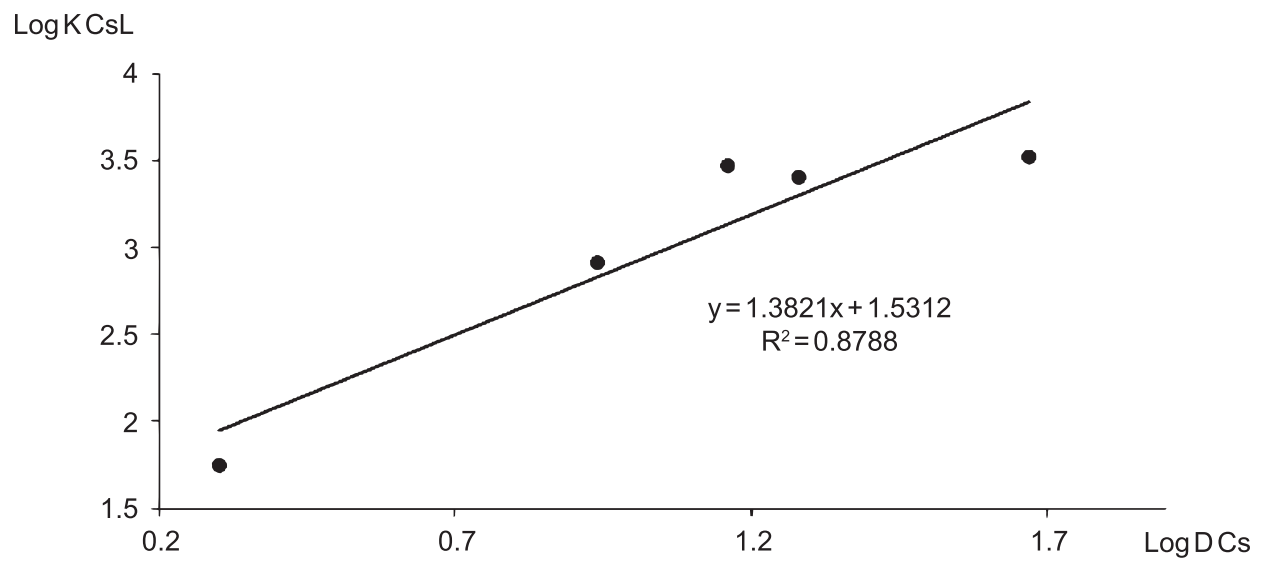

Figure 3. A correlation between $\log D_{\mathrm{CS}}{ }^{\mathrm{L}}$ and $\log K_{\mathrm{CSL}}{ }^{\mathrm{RTIL}}$ values for $15 \mathrm{C} 5,18 \mathrm{C} 6, \mathrm{DB} 18 \mathrm{C} 6, \mathrm{DB} 21 \mathrm{C} 7$ and DB24C8 at $22-25^{\circ} \mathrm{C}$. 
In contrast to the reports, ${ }^{[15,20]}$ in our case we have a single RTIL. Therefore $\log \mathrm{D}_{\mathrm{Cs}}$ is a constant for all the $\mathrm{L}$ series. At the same time $[\mathrm{L}]^{\circ} \gg[\mathrm{Cs}]^{\circ}$, and most of crowns used are poorly soluble in water, then an equilibrium concentration $[\mathrm{L}]^{\mathrm{RTIL}}$ should not change significantly for different crowns and would be close to $[\mathrm{L}]^{\circ}$.

Therefore, a dependence of $\log D_{\mathrm{Cs}}^{\mathrm{L}}$ on $\log K_{\mathrm{CsL}}{ }^{\mathrm{RTIL}}$ should be linear with the slope 1 . Some deviation from this slope, presented in Figure 3 is probably due to some change of crowns solubility in an aqueous phase relative to each other. This relative solubility should also correlate with CsL complex stability: the less water soluble crowns form more stable complexes CsL in a RTIL phase. This statement is valid only for hydrophobic crowns. For example, 12C4 is water soluble. Then it reveals no extraction enhancement although the corresponding $[\mathrm{Cs}(12 \mathrm{C} 4)]^{+}$complex is rather stable in the $[\mathrm{BMIM}]\left[\mathrm{N}(\mathrm{Tf})_{2}\right]$ phase.

\section{Conclusions}

The thermodynamic stability of complexes in RTIL is of key importance for cesium extraction from aqueous phase into RTIL. The $\log D_{\mathrm{Cs}}{ }^{\mathrm{L}}$ values increase steadily from 0.30 to 1.7 when $15 \mathrm{C} 5$ is changed for $18 \mathrm{C} 6$, DB18C6 and DB21C7, but then they decrease up to 0.94 (DB24C8). The maximal value for $\log D_{\mathrm{Cs}}{ }^{\mathrm{L}}$ is observed for $\mathrm{DB} 21 \mathrm{C} 7$ with the best fitting cesium ion radius and cavity size. For a set of crowns 12C4, 15C5, 18C6, DB18C6, DB21C7, and DB24C8 in $[\mathrm{BMIM}]\left[\mathrm{N}(\mathrm{Tf})_{2}\right]$ a linear relationship between $\log D_{\mathrm{CS}}^{\mathrm{L}}$ and $\log K_{\mathrm{CsL}}$ is found and is interpreted.

Acknowledgements. The authors would like to thank the Russian Foundation for Basic Research (Project No. 13-0800246) for the financial support of this work.

\section{References}

1. Bradshaw J.S., Izatt R.M. Acc. Chem. Res. 1997, 30, 338-345.

2. Takeda Y., Kawarabayashi A., Endō K., Yahata T., Kudo Y., Katsuta S. Anal. Sci. 1998, 14, 215-223.

3. Robak W., Apostoluk W., Maciejewski P. Anal. Chim. Acta 2006, 569, 119-131.
4. Levitskaia T.G., Maya L., van Berkel G.J., Moyer B.A. Inorg. Chem. 2007, 46, 261-272.

5. Abramov A.A. Vestnik Mosk. Univ., Ser. 2: Khim. (Moscow Univ. Chem. Bull.) 2000, 41, 3-15 (in Russ.).

6. Dai S., Ju Y.H., Barnes C.E. J. Chem. Soc., Dalton Trans. 1999, 1201-1202.

7. Visser A.E., Swatloski R.P., Reichert W.M., Griffin S.T., Rogers R.D. Ind. Eng. Chem. Res. 2000, 39, 3596-3604.

8. Chun S., Dzyuba S.V., Bartsch R.A. Anal. Chem. 2001, 73, 3737-3741.

9. Yakshin V.V., Tsarenko N.A., Koshcheev A.M., Tananaev I.G., Myasoedov B.F. Radiochemistry (Moscow, Russian Federation) 2012, 54, 54-58.

10. Garvey S.L., Dietz M.L. Sep. Purif. Technol. 2014, 123,145-152.

11. Sun Tao Xiang, Shen Xing Hai, Chen Qing De Sci. China Chem. 2013, 782-788.

12. Turanov A.N., Karandashev V.K., Baulin V.E. Solvent Extr. Ion Exch. 2012, 30, 244-261.

13. Germani R., Mancini M.V., Spreti N., Di Profio P., Savelli G. Green and Sustainable Chemistry 2011, 1, 155-164.

14. Torrejos R.E.C., Nisola G.M., Park M.J., Beltran A.B., Seo J.G., Lee S.-P, Chung W.-J. Desalination and Water Treatment 2015, 53, 2774-2871.

15. Vendilo A.G., Djigailo D.I., Rönkkömäki H., Lajunen M., Chernikova E.A., Lajunen L.H.J., Pletnev I.V., Popov K.I. Mendeleev Commun. 2010, 20, 122-124.

16. Vendilo A.G., Djigailo D.I., Smirnova S.V., Torocheshnikova I.I., Popov K.I., Krasovsky V.G., Pletnev I.V. Molecules 2009, 14, 5001-5016.

17. Arnaud-Neu F., Delgado R., Chaves S. Pure Appl. Chem. 2003, $75,71-102$.

18. IUPAC Stability Constants Database. Version 2007, Academic Software, Timble, UK.

19. Vendilo A., Popov K., Lajunen M., Chistov V., Djigailo D., Rönkkömäki H., Privalov V., Pletnev I. Polyhedron 2014, 81, 341-348.

20. Vendilo A.G., Chistov V.I., Privalov V.I. Russ. J. Inorg. Chem. 2012, 57, 629-633.

21. Buschmann H.-J., Cleve E., Denter U., Schollmeyer E. J. Phys. Org. Chem. 1997, 10, 781-785.

22. Pedersen C.J. Angew. Chem., Int. Ed. 1988, 27, 1021-1027.

23. Lamb J.D., Izatt R.M., Swain C.S., Christensen J.J. J. Am. Chem. Soc. 1980, 102, 475-482.

24. Gjikaj M., Adam A. Z. Anorg. Allg. Chem. 2006, 632, 2475-2480.

25. Ellerman J., Bauer W., Schuetz M., Heinemann F.W., Moll M. Monatshefte fuer Chemie 1998, 129, 547-566.

26. Ozutsumi K., Natsuhara M., Ohtaki H. Bull. Chem. Soc. Jpn. 1989, 62, 2807-2818.

27. Dang L.X. J. Am. Chem. Soc. 1995, 117, 6954-6969. 